\title{
Effect of agrotechnical and chemical practices on Fusarium rot root in sugar beet production
}

\author{
A.A. Maui ${ }^{1}$, S.A. Aipeisova ${ }^{2}$, N.A. Utarbaeva ${ }^{3 *}$, A.V. Matsyura $^{4}$ \\ ${ }^{1}$ Kazakh National Women's Teacher Training University, Kazakhstan \\ ${ }^{2}$ Baishev University, Aktobe, Kazakhstan \\ ${ }^{3}$ K. Zhubanov Aktobe Regional State, Aktobe, Kazakhstan \\ ${ }^{4}$ Altai State University, Barnaul, Russian Federation \\ *Corresponding author E-mail: nurlyqul.utarbaeva@mail.ru
}

\section{Received: 08.09.2020. Accepted 27.10.2020}

\begin{abstract}
Sugar beet is one of the economically significant industrial crops for the south and southeast of Kazakhstan. In the conditions of Kazakhstan, the best predecessors of sugar beet are winter wheat and alfalfa, which contribute to the improvement of the susceptibility of beet rot. Early plowing by the semi-pair type in the second decade of August allows reducing the susceptibility of root crops to Fusarium rot by $18 \%$. It is shown that 6 centner/ha of wheat straw on the artificial background contributed to decrease in the prevalence of Fusarium rot, on average 1.4 times, Rhizoctoniosis rot - 1.2 times compared with the control. Increasing the rate of nitrogen and phosphate fertilizers contribute to the development of root rot (2-3 times) of sugar beet. To reduce the severity of rotten root crops (from 1.3 to 2.5 times), 6 t/ha of wheat straw are proposed to be applied to the soil together with $\mathrm{N}_{90} \mathrm{P}_{75} \mathrm{~K}_{70}$. Seed treatment with tachigaren seed, rovral and fundazol reduces the development of rot by $8.1-16.6 \%$ and leads to an increase in yield of root crops by $31.5-50.2 \mathrm{c} / \mathrm{ha}$.
\end{abstract}

Keywords: Agrotechnical methods; Disinfectant; Fusarium rot; Precursor; Sugar beet

\section{Introduction}

Sugar beet in Kazakhstan is the only source of local raw materials for sugar production. It is cultivated under conditions of irrigation in Almaty and Zhambyl regions. The planting of sugar beet in the country in 1990-ies reached 80.0 thousand hectares. Unfortunately, at present its production in Kazakhstan is in a difficult situation. Therefore, from 1990-ies the yield of root crops decreased from 450 to $110 \mathrm{c} /$ ha, the sugar content from $14.4 \%$ to $9.5 \%$. Kazakhstan produces only $2-3 \%$ of the required sugar. One of the main reasons for this situation is the mass distribution of various rotten root crops on sugar beet plantations.

Root rot is the most dangerous and harmful disease of this crop, the causative agents of which are either inside the root crops or in the soil. One of the ways to combat rot of root vegetables are agro technical and chemical measures.

Long-term cultivation of a single plant species in the same field for many years, as a rule, leads to accumulation of pathogens characteristic of a given crop in the soil. This is one of the main reasons for the massive spread of plant diseases caused by soil microorganisms. In order to improve the soil from harmful organisms, it is necessary to change the soil complex of microorganisms in a targeted manner (Ikeda et al., 2015).

Dead vegetation residues are a selection factor for soil microcenosis. The differentiating action of plants and their residues on the formation of microbial cenoses explained by the difference in root excretions. The latter contributes to the development and accumulation in the soil of certain types of bacteria, fungi and actinomycetes. This indicates that the selection of precursors can regulate the formation of beneficial microorganisms and reduce the harmfulness of many plant diseases (Spasih et al., 1990).

Based on Verticillium dahliae, its shows that all plants, including crops, participating in crop rotation, stimulate the germination of microsclerotia in the soil. According to Selivanova (2013), this leads to partial purification of the soil from infection during the cultivation of non-affected plants. In the practice of plant protection, including with sugar beet diseases, agro technical method of control is widely used. One of the main methods of restricting the development of Fusarium rot is the strict observance of crop rotations and the allowable level of accumulation of sugar beet. Crop rotation over $20 \%$ leads to the accumulation of pathogens of Fusarium rot in the soil and a significant increase in plant diseases (Maui, 2014).

Research of beet crop rotations, principles of alternation of crops in them, issues of placement of sugar beet in crop rotation by the best predecessors were done by many researchers. Research by Nurpeisov et al. (2012) revealed that the yield and quality of sugar beet is much higher in the fields of crop rotation and when placed on the best predecessors than in permanent sowing. So, on average over 13 years, the maximum yield of sugar beet 582-565 centners per hectare was obtained from the reservoir. The reservoir turnover of a three-year-old alfalfa, the sugar harvest amounted from $97.9 \mathrm{c} / \mathrm{ha}$ to $96.1 \mathrm{c} / \mathrm{ha}$. Repeated sowing of beets on beets for three years significantly reduces the yield of roots and the collection of sugar by 60-80 c/ha. At the same time, the yield and quality decrease are not dependent on the application of mineral and organic fertilizers. At the same time, there is a sharp increase in the disease of sugar beet root and root rot.

The decrease in the development of root decay on cereals and industrial crops while improving the agro technical background shows the results of many studies (Secor et al., 2014; Ikeda et al., 2015; Landschoot et al., 2013; Lai et al., 2020; Rivera et al., 2008; Covey et al., 2014). Dry white rot (Crinipellis spp.) Was discovered for the first time in Kazakhstan in 1969 by T.F. Alkhovskaya. This rot affected root crops in hot weather (July, August). The causative agent of the disease, the author considered the fungus Rhizoctonia solani. Later, it was found that the causative agent of the disease are fungi of the genus Crinipellis Pat, which belong to the order Agaricales. According to the data A.V. Zagursky and A.S. Dotsenko in Kyrgyzstan, annual losses of beet 
harvest due to the defeat of root rot by its rot make up more than $10 \%-50 \%$. Sugar content of affected root crops is only 6.6 $7.3 \%$ (Dotsenko, 1980, Zagurskiy, 2016). In recent years, beets sowing farms of Almaty and Zhambyl regions on sugar beet crops there has been an increase in loss storing this valuable crop as a result of the spread of root rot in its crops. This situation was created due to the haphazard introduction of beet farming, the inhibition of sugar beet sowing, prolonged mixing of sugar beets on beets, improper use of fertilizers, violation of other technology requirements for cultivating this crop. Therefore, all the factors of agrocenosis, which are more or less related to this problem, have become a subject study of further research.

\section{Materials and Methods}

Experimental work was done in laboratory and field conditions of irrigated lands of Almaty oblast of Kazakhstan in $1998-2017$.

The object of research is sugar beet on the infected lands of the south and southeast of Kazakhstan.

\section{Field experiments}

Field and plot experiments to study the effect of individual factors and their combinations on the phytosanitary condition of infected lands with root rot pathogens and sugar beet productivity were carried out on the stationary experience of the Kazakh Research Institute of Agriculture and Plant Growing, in the Kazakh Research Institute of Plant Protection and Kazakh State Women's Teacher Training University in naturally infected sites and on artificial infectious backgrounds. The size of the experimental plots was 100 square $\mathrm{mm}$, repetition of 4 times. The plots were placed in a systematic (sequential) order of options in each repetition. In order to fully cover the variegations of the repetition site, the replicates were placed in a randomized way. Artificial infectious backgrounds of sugar beet diseases were created by plowing up the remains of affected root-crops and a long-term monoculture of sugar beets (over 10 years), in necessary cases, the background was strengthened with the help of a pure fungus culture.

Lands of Kazakhstan were determined by route surveys of sugar beet fields of farms in Almaty and Zhambyl regions. The survey routes were planned in such a way as to cover the area of sugar beet cultivation as widely as possible, paying particular attention to areas with a high concentration of crops. During the examination, diagonal of the beet plot on each fifty-fifth row was applied to ten-meter samples, in which the total number of plants and the number of affected roots were counted. The study of the effect of crop rotations, fertilizers and plowing of straw on the development of root rot was carried out in field experiments of the department of agrotechnology and agrochemistry of the Kazakh Research Institute of Agriculture and Plant Growing. Plowing straw with ordinary plows with dumps to a depth of $25 \mathrm{~cm}$ was carried out at the end of October (after carrying out pre-arable irrigation and application of the main fertilizer). Before being introduced into the soil, winter wheat straw was ground by a combine up to 4-5 $\mathrm{cm}$. The effect of the dressing agents was determined by plot experiments with a recorded area of fifty square meters with a sixfold repetition. The following preparations were studied in the experiments: foundationazole (consumption rate of the preparation is $3 \mathrm{~kg} / \mathrm{t}$ of seeds), phenoram (2 kg/t), rovral (3 kg/t), apron $(6 \mathrm{~kg} / \mathrm{t})$, kolfugo-super $(2 \mathrm{l} / \mathrm{t})$, derozal $(2 \mathrm{~kg} / \mathrm{t})$, sulfocarbation $(4 \mathrm{~kg} / \mathrm{t})$ and tachigaren $(6 \mathrm{~kg} / \mathrm{t})$. In the control embodiment, the seeds were not etched. TMTD at a rate of $4 \mathrm{~kg} / \mathrm{t}$ of seeds was used as a reference. Etching was carried out one to two days before sowing. The productivity of the plot experiments was determined by weighing all beet root crops of healthy and diseased plants. The sugar content of sugar beet root crops was determined in the laboratory of sugar beet of the Kazakh Research Institute of Agriculture and Plant Growing.

\section{Laboratory experiments}

The isolation of pathogens into a pure culture was carried out using seeding methods on nutrient media or in a moist chamber. To this end, the roots of sugar beet, affected by rot, washed in a stream of tap water and dried with filter paper. Then with a wet swab soaked in alcohol, surface sterilization was performed. The roots were cut vertically and horizontally into several parts. On the border of healthy and affected tissue, small pieces were taken and following the rules of asepsis, they were placed on wort agar in Petri dishes. The isolation of root rot pathogens was carried out from samples of affected plants by the accumulative culture method in a humid chamber. Pieces of the affected tissue were laid out on wet filter paper in sterile Petri dishes and placed in a thermostat at $26^{\circ} \mathrm{C}$. After two to three days, fungal mycelium appeared on the affected tissues, which was then screened on agar medium. Fungi isolated into a pure culture were determined on the $15^{\text {th }}$ day of sowing.

Phytopathological analysis of plants affected by root rot was carried out according to the methods of N. A. Naumov, while root crops of sugar beet affected by rot were washed in a stream of tap water and dried with filter paper. Then, with a wet swab soaked in alcohol, surface sterilization was performed. Root crops were cut vertically and horizontally into several parts. Small pieces were taken at the border of healthy and diseased tissue, and, following aseptic rules, they were placed on acidified agar in Petri dishes.

\section{Results}

From 1998 to 2017, author of article with employees of the Department of Agriculture of the Kazakh Research Institute of Agriculture and Plant Growing and chief agronomists of sugar factories in the Almaty and Zhambyl regions, the characteristics of the placement of sugar beet in crop rotation were studied to limit the development of rotten root crops during the growing season. Over the years, 727 beet fields were surveyed, on which the time of the previous sowing of beets was established, the number of affected root crops was calculated and the crop yield at the site was determined in the current year (Table 1).

Table 1. The influence of the period of beet return to the former field on the prevalence of root rot (1998-2017).

\begin{tabular}{lcc}
\hline \multicolumn{1}{c}{ Return of beet to its former place } & The prevalence of rot, $\%$ & Yield, c/ha \\
\hline The permanent cultivation of beets from 1961 & 98.6 & 90.8 \\
After 1-2 years & 78.9 & 110.4 \\
After 3-4 years & 23.0 & 223.5 \\
In 5-6 years & 13.2 & 284.2 \\
After 8 years & 9.8 & 334.0 \\
After 10 years & 0.0 & 424.7 \\
\hline
\end{tabular}

The data of the Table 1 show that the smaller the time interval between the cultivation of beets in one place, the more it is subjected to decay of root crops. So, in farms where beets were returned to the former site after 1-2 years, the prevalence of rot 
reached $78.9 \%$. With a 3-4-year-old return, the incidence of rot decreases, but remains at a fairly high level - $23 \%$. The smallest manifestation of rot is noted in crop rotations, where the beets return to their former place no earlier than 8 years or more, i.e., the fields turned out to be practically free from soil infection of root rot ( $9.8 \%$ or less of affected root crops on average), and this, in turn, contributes to an increase in yield (334-425 c/ha). Based on the data presented, it can be concluded that sowing beets repeatedly in the same area is desirable not earlier than in 5-6 years. The study of the effect of predecessors on the susceptibility of sugar beet to rot of root crops carried out in a stationary experiment, the Kazakh Research Institute of Agriculture and Plant Growing, founded in 1961. According to the data obtained, winter wheat and alfalfa to some extent contributed to a decrease in the susceptibility of sugar beet to root rot (Table 2). At the same time, we noted that predecessors such as corn, potatoes and safflower help to increase the susceptibility of sugar beet roots to rot. In monoculture, the incidence of rotten root crops reached $41.7 \%$ at the time of harvesting (Table 2).

Table 2. The effect of sugar beet precursors on rot and productivity of root crops in the inpatient experiment.

\begin{tabular}{lcccc}
\hline \multicolumn{1}{c}{ Predecessors } & $\begin{array}{c}\text { Disease } \\
\text { development, } \%\end{array}$ & $\begin{array}{c}\text { Yield, } \\
\text { c/ha }\end{array}$ & Sugar content, \%o & $\begin{array}{c}\text { Sugar collection, } \\
\text { c/ha }\end{array}$ \\
\hline Alfalfa Reverse & 8.0 & 392 & 14.8 & 58.0 \\
Winter wheat & 5.2 & 405 & 15.0 & 60.8 \\
Barley & 7.5 & 372 & 13.5 & 49.5 \\
Soy & 7.2 & 365 & 13.7 & 50.0 \\
Corn & 9.2 & 331 & 13.0 & 43.0 \\
Potatoes & 15.7 & 247 & 12.2 & 30.1 \\
Safflower & 20.7 & 220 & 11.9 & 26.2 \\
Sugar beet 2 y & 9.5 & 300 & 12.9 & 38.7 \\
Sugar beet 3 y & 27.7 & 210 & 12.0 & 25.2 \\
Sugar beet 10 years & 32.5 & 165 & 11.7 & 1.0 \\
Sugar beet (in monoculture 38 years) & 41.7 & 110 & 11.0 & 12.3 \\
\hline
\end{tabular}

In the stationary experiment, the number of primordial fungi of the genus Fusarium was determined depending on the precursors during the growing season. The purpose of this experiment was to clarify the characteristics of the dynamics of the fungi of the genus Fusarium, depending on the type of plants in the crop rotation. Analysis of soil samples taken in April showed that the initial infection of the soil of the experimental plots employed for these crops varied significantly. At the same time, the number of the primordia of the Fusarium fungi in the repetition of variants varied from 25.6 to 55.1 thousand pcs per $1 \mathrm{~g}$ of dry soil (Table 3 ).

Table 3. Dynamics of the content in the soil of the primordia of the fungi of the genus Fusarium on different precursors of sugar beet in a stationary experiment.

\begin{tabular}{|c|c|c|c|c|c|}
\hline \multirow{2}{*}{ Predecessor } & \multicolumn{5}{|c|}{ The number of primordia of fungi Fusarium, pieces/g of soil } \\
\hline & April & June & July & August & September \\
\hline Steam & 26640 & 35360 & 43680 & 41600 & 39520 \\
\hline Barley & 38160 & 39520 & 43670 & 43590 & 45580 \\
\hline Oats & 25680 & 38880 & 38520 & 42000 & 33280 \\
\hline Lucerne + Ryegrass & 46200 & 43050 & 47550 & 52500 & 46640 \\
\hline Barley + Alfalfa & 55120 & 50880 & 49350 & 53550 & 52500 \\
\hline Corn & 48150 & 47700 & 54570 & 57200 & 58300 \\
\hline
\end{tabular}

In a couple of cases in June and July, a marked increase in the buds of the Fusarium fungi is observed, compared with the initial period. If in April the amount of propagules of Fusarium was, on average, 25.6 thousand pcs/g of soil, in June - 35.3 thousand, and in July - 45.6 thousand. At the end of summer and early autumn (August-September) there is a slight decrease in their number, respectively, 41.6 and 39.5 thousand units per gram of soil. Nevertheless, it should be noted that the accumulated amount of infection by the end of September is much more than at the beginning of the growing season - 39.5 thousand pcs/g (control - 25.6 thousand units/year). For corn in early summer, a slight decrease in the number of Fusarium buds in the soil was noted. However, in the future, there is a gradual increase in their numbers until the harvest. So, if the number of propagules in July amounted to 54.5, in August - 57.2, in September - 58.3 thousand units/g of soil. Given the lack of a clear pattern in the dynamics of the number of Fusarium fungi, depending on the sugar beet precursors, the determination of soil infection by the main causative agents of rot was considered appropriate to be carried out at the beginning and end of the vegetation period. According to the research results, the number of Fusarium fungi varied during the growing season of sugar beets (Table 4).

Table 4. The effect of sugar beet precursors on the content in the soil of the primordia of the Fusarium fungi (in pieces/g of soil).

\begin{tabular}{lrr}
\hline \multicolumn{1}{c}{ Predecessors } & \multicolumn{2}{c}{ The number of primordia of fungi Fusarium, pieces/g of soil } \\
\cline { 2 - 3 } & at the beginning & at the end \\
\hline West German barley & 44540 & 24200 \\
Oats & 40290 & 31080 \\
Alfalfa under the cover of barley & 43200 & 22600 \\
Corn & 58560 & 25520 \\
Steam & 34800 & 24640 \\
\hline
\end{tabular}

At the beginning of the growing season (end of April), relatively high population of soil with pathogens of rot is observed in maize. One $\mathrm{g}$ of air-dry soil, taken from this predecessor, contains 58.5 thousand propagules of fusarium. According to the predecessors of oats, alfalfa under the cover of barley and barley, the population of the soil with Fusarium fungi was close and amounted to 40.2 , 
43.3 and 44.5 propagules in $1 \mathrm{~g}$ of air-dry soil. Relatively lower content in the soil of propagules Fusarium is noted by a couple 34.8 thousand pieces/g of soil. By the end of the vegetative period of sugar beet, a significant decrease in the magnitude of the infectious load is observed for all predecessors. Thus, the next for barley, alfalfa under a cover of barley and corn, the number of Fusarium germs is almost two or two times less than that in the initial period of the growing season of sugar beet. According to our data, in the conditions of the south and southeast of Kazakhstan, the best predecessors of sugar beet are winter wheat and alfalfa. The above predecessors contributed to the reduction of susceptibility of root crops and the number of fungi of the genus Fusarium during the growing season of sugar beet.

\section{The effect of organic fertilizers on the development of carnod rot and sugar beet productivity}

Of considerable importance among agrotechnical measures in the fight against fusarial sugar beet rot is tillage, which, if carried out correctly, significantly changes the conditions for the existence of phytopathogens in the soil and contributes to the improvement of the phytosanitary situation on sugar beet crops. We have shown that the effect of underwater plowing at depths on sugar beet infestation of root crops was insignificant. At the same time, a significant impact of the timing of plowing was determined. The effectiveness of early plowing of the slaughter ( 2 decade of August) as a method of receiving the main tillage of the semi-pair type as compared with the late period (3-decade of September) is shown.

During early plowing, the prevalence of sugar beet rot of root crops was $9.0 \%$, which is 1.7 times less than in the control (15.3\%), the yield increase was $266.2 \mathrm{c} /$ ha (in the control variant - 231.6 centners per hectare). Inter-row loosening under irrigation conditions is an important agrotechnical technique that improves the water-physical properties of the soil. Deep loosening of interrow spacing (by 16-18 cm) after vegetative irrigation contributed to reducing the damage of beets to root rot by more than 1.5 times compared to the variant where the soil was loosened to a depth of $10-12 \mathrm{~cm}$. The data of our observations on the development of root rot of sugar beet when plowing winter wheat straw as fertilizer is in Table 5 . On a natural infectious background, plowing up straw of winter wheat allows reliably reducing the susceptibility of root crops by rot, as compared to the control variant $\left(\mathrm{N}_{90} \mathrm{P}_{75} \mathrm{~K}_{70}\right.$ - background), and the variant in which 60 t per hectare of manure were added along with $\mathrm{N}_{90} \mathrm{P}_{75} \mathrm{~K}_{70}$.

The data obtained give reason to conclude that the infectious background Fusarium spp. and Rhizoctonia solani, plowing into the soil of straw not only increases the productivity of sugar beet, but also reduces its damage by rotting root crops. Accounting has shown that adding $6 \mathrm{t} / \mathrm{ha}$ of wheat straw to a natural infectious background to the soil contributed to reducing the number of affected sugar beet roots by up to two and a half times compared with the control without straw against the background of relatively weak development of rot. Against an infectious background, a decrease in the susceptibility of rot was: on an infectious background, Fusarium spp., on average by 1.3 times, and against the background of Rhizoctonia solani - by 1.2 times lower compared with the control. The decrease in plant damage by plowing straw can be explained by the activation of saprophytic microflora. In competition for food and place, they inhibit the development of pathogens or destroy their infectious primordia. When straw is decomposed, substances with a bactericidal and fungicidal action released.

Table 5. The effect of plowing straw of winter wheat on the development of root rot and productivity indicators of sugar beet, 2000-2007.

\begin{tabular}{|c|c|c|c|c|c|c|}
\hline \multirow[b]{2}{*}{ Options } & \multicolumn{3}{|c|}{ The number of affected root crops, \% } & \multirow[b]{2}{*}{$\begin{array}{l}\text { Yield, } \\
\text { c/ha }\end{array}$} & \multirow[b]{2}{*}{$\begin{array}{c}\text { Sugar } \\
\text { content, } \\
\%\end{array}$} & \multirow[b]{2}{*}{$\begin{array}{c}\text { Sugar } \\
\text { harvest, } \\
\text { c/ha }\end{array}$} \\
\hline & $\begin{array}{c}\text { On a natural } \\
\text { infectious } \\
\text { background }\end{array}$ & $\begin{array}{l}\text { On artificial in } \\
\text { fusarium rot }\end{array}$ & $\begin{array}{l}\text { ious background } \\
\text { rhizoctonia rot }\end{array}$ & & & \\
\hline $\begin{array}{l}\mathrm{N}_{90} \mathrm{P}_{75} \mathrm{~K}_{70} \mathrm{~kg} / \mathrm{ha}- \\
\text { background (control) }\end{array}$ & 2.0 & 58.3 & 44.3 & 577 & 14.1 & 81.4 \\
\hline Background + 60 t/ha dung & 1.5 & 50.9 & 38.3 & 625 & 13.6 & 85.0 \\
\hline $\begin{array}{l}\text { Background }+6 \text { t/ha wheat } \\
\text { straw }\end{array}$ & 0.8 & 40.1 & 36.6 & 629 & 14.4 & 90.6 \\
\hline $\begin{array}{l}\text { Background }+3 \mathrm{t} / \mathrm{ha} \\
\text { wheat straw }\end{array}$ & 0.8 & 40.0 & 38.1 & 613 & 14.4 & 88.3 \\
\hline $\mathrm{HCP}_{05}$ & 0.26 & 11.4 & 5.8 & 8.9 & 14.7 & 71.9 \\
\hline
\end{tabular}

Further experiments were carried out to study the effect of various doses of fertilizers and the ratios of nutrients on the susceptibility of sugar beet roots to rot (Table 6).

Table 6. Influence of various norms of fertilizers on rottenness, yield and sugar content of sugar beet roots, 2003-2005.

\begin{tabular}{|c|c|c|c|c|c|c|}
\hline \multirow{2}{*}{ Indicators } & \multirow{2}{*}{ Year } & \multicolumn{4}{|c|}{ It is brought under beet of batteries, $\mathbf{~ k g ~ / ~ h e c t a r e ~}$} & \multirow{2}{*}{ Experiment error 05} \\
\hline & & $\mathbf{N}_{120} \mathbf{P}_{75} \mathbf{K}_{70}$ & $\mathbf{N}_{\mathbf{2 4 0}} \mathbf{P}_{\mathbf{1 5 0}} \mathbf{K}_{\mathbf{7 0}}$ & $\mathbf{N}_{\mathbf{2 4 0}} \mathbf{P}_{\mathbf{7 5}} \mathbf{K}_{\mathbf{7 0}}$ & $\mathbf{N}_{120} \mathbf{P}_{150} \mathbf{K}_{70}$ & \\
\hline \multirow{4}{*}{$\begin{array}{l}\text { Struck by root rot, } \\
\%\end{array}$} & 2003 & 1.2 & 3.6 & 2.7 & 4.5 & 0.3 \\
\hline & 2004 & 0.8 & 2.8 & 1.7 & 3.3 & 0.4 \\
\hline & 2005 & 2.5 & 8.0 & 4.6 & 3.6 & 0.7 \\
\hline & average & 1.5 & 4.8 & 3.0 & 3.8 & \\
\hline \multirow{4}{*}{ Root crops, c/ha } & 2003 & 597 & 581 & 646 & 578 & 15.3 \\
\hline & 2004 & 645 & 740 & 628 & 686 & 27.9 \\
\hline & 2005 & 564 & 596 & 595 & 632 & 27.1 \\
\hline & average & 602 & 639 & 623 & 632 & \\
\hline \multirow{4}{*}{ Sugar content, \% } & 2003 & 14.0 & 13.2 & 11.5 & 13.5 & 0.86 \\
\hline & 2004 & 14.2 & 14.0 & 12.3 & 13.8 & 0.86 \\
\hline & 2005 & 12.9 & 12.1 & 12.2 & 13.8 & 0.47 \\
\hline & average & 13.7 & 13.1 & 12.0 & 13.7 & \\
\hline
\end{tabular}


The data of our experiments are consistent with the findings of those authors who note the negative effect of elevated rates and a one-sided increase in nitrogen and phosphorus on plant resistance to disease. An increase in the rate of nitrogen and phosphate fertilizers contributed to the increase in the susceptibility of beets to root rot. An increase in the nitrogen and phosphorus standards by half compared with the recommended doses of fertilizers significantly increased the development of root rot. Despite this, the yield in this variant was $37 \mathrm{c} /$ ha more than in the control. This is probably due to the increased growth of plant biomass at high doses of nitrogen and phosphorus. However, the sugar content dropped by $0.6 \%$, and the collection of sugar per unit area did not have a significant difference from the control.

\section{The influence of various protectants on the development of sugar beet root beetle}

With the help of agrotechnical methods it is not always possible to prevent the mass susceptibility of sugar beet roots to rot. Therefore, the use of chemical means of protection for presowing treatment of seeds can also help control the development of rot of root crops. Treated sugar beet seeds are less susceptible to soil and seed infection in the early stages of development, and their further infestation with pathogens of rot will be significantly lower than untreated seeds. Research results show that all drugs had a positive effect on seed germination (Table 7). The highest efficiency is noted in the variants with rovral $(2 \mathrm{~kg} / \mathrm{t})$, tachigaren (6 kg/t) and fundazol $(3 \mathrm{~kg} / \mathrm{t})$. When used for processing, laboratory germination of seeds was, respectively, 85\%, $84.5 \%$, $83 \%$ and exceeded control, respectively, by $7 \% ; 5.5 \%$ and $5 \%$, the variant with the standard - by $3 \% ; 1.5 \%$ and $1 \%$. The preparations also increased field germination of seeds, on average, by $1.3-12.8 \%$, as compared with the control.

In the phase of the second pair of true leaves in the variants with the use of tachigaren $(6 \mathrm{~kg} / \mathrm{t}), \mathrm{rovral}$ and fundiazol $(3 \mathrm{~kg} / \mathrm{t})$, the development of the root carrot was, on average, $1.6-5.3 \%$, which is $11.1-14,8 \%$ lower compared to control. The prevalence of these variants was also $8.8 \%, 5.4 \%$ and $5.1 \%$, respectively; lower than in the variant with TMTD, the consumption rate of the preparation is $4 \mathrm{~kg} / \mathrm{t}$. Positive results were obtained when treating the seeds of sugar beet with the preparations $\mathrm{x}$-super $(2 \mathrm{l} / \mathrm{t})$ and sulfocarbation (4 kg/t). A similar pattern was observed during the harvest period. Thus, when tachigaren treated seeds, the degree of damage to plants by rotting root crops was reduced by $16.6 \%$. Against the rot of root vegetables, the rovral and fundazol preparations in the norm of $3 \mathrm{~kg} / \mathrm{t}$ also differed in high efficiency, and during the treatment with these preparations, the intensity of the development of the rot decreased, respectively, by $7.9 \%$ and $8.1 \%$.

Table 7. The effectiveness of seed disinfectants against the root of seedlings and rot of sugar beet roots, 2005-2007.

\begin{tabular}{|c|c|c|c|c|c|c|c|c|}
\hline \multirow{3}{*}{ Options } & \multirow{2}{*}{\multicolumn{2}{|c|}{ Seed germination }} & \multirow{2}{*}{\multicolumn{4}{|c|}{$\begin{array}{l}\text { Affection, } \% \\
\text { By the root }\end{array}$}} & \multirow{3}{*}{$\begin{array}{l}\text { Yield, } \\
\text { (c/ha) }\end{array}$} & \multirow{3}{*}{$\begin{array}{c}\text { Sugar } \\
\text { content } \\
(\%)\end{array}$} \\
\hline & & & & & & & & \\
\hline & Laboratory & Field & $\begin{array}{l}\text { Amazed } \\
\text { plants }\end{array}$ & $\begin{array}{c}\text { Disease } \\
\text { progression }\end{array}$ & $\begin{array}{l}\text { Amazed } \\
\text { plants }\end{array}$ & $\begin{array}{c}\text { Disease } \\
\text { progression }\end{array}$ & & \\
\hline $\begin{array}{l}\text { Control - Without } \\
\text { treatment }\end{array}$ & 78.0 & 59.2 & 42.0 & 16.4 & 68.5 & 24.12 & 305.6 & 14.9 \\
\hline $\begin{array}{l}\text { TMTD, } 4.0 \mathrm{~kg} / \mathrm{t} \text { - } \\
\text { (standard) }\end{array}$ & 82.0 & 63.7 & 32.1 & 10.4 & 52.0 & 20.25 & 332.6 & 14.8 \\
\hline Tachigarin, $6.0 \mathrm{~kg} / \mathrm{t}$ & 83.5 & 72.0 & 16.4 & 1.6 & 35.0 & 7.5 & 355.8 & 16.5 \\
\hline Apron, 6.0 kg/t & 79.5 & 61.5 & 33.4 & 12.6 & 66.5 & 22.5 & 328.3 & 14.9 \\
\hline Fundazol, $3.0 \mathrm{~kg} / \mathrm{t}$ & 83.0 & 66.0 & 18.1 & 5.3 & 48.5 & 16.25 & 337.1 & 15.7 \\
\hline Kolfugo-super, 2.0 kg/t & 82.5 & 66.5 & 26.4 & 6.4 & 62.5 & 22.37 & 330.4 & 15.2 \\
\hline Derozol, $2.0 \mathrm{~kg} / \mathrm{t}$ & 82.0 & 63.7 & 30.3 & 10.3 & 50.0 & 22.87 & 330.7 & 15.0 \\
\hline Sulfocarbation, $4.0 \mathrm{~kg} / \mathrm{t}$ & 81.5 & 64.0 & 25.8 & 8.6 & 51.0 & 23.0 & 333.5 & 15.1 \\
\hline Fenor, $3.0 \mathrm{~kg} / \mathrm{t}$ & 80.5 & 62.5 & 38.1 & 16.0 & 61.0 & 230 & 328.4 & 15.0 \\
\hline Rovral, $3.0 \mathrm{~kg} / \mathrm{t}$ & 85.0 & 66.5 & 19.6 & 5.0 & 45.0 & 16.0 & 343.5 & 15.9 \\
\hline $\mathrm{HCP}_{05}$ & 1.2 & 3.6 & 8.3 & 5.7 & 6.8 & 4.8 & 10.7 & 0.4 \\
\hline
\end{tabular}

The use of seed treaters made it possible to increase the productivity of sugar beet roots. Thus, the yield in the variants using tachigaren, rovral and fundazol, respectively, was from 337.1 to $355.8 \mathrm{c} / \mathrm{ha}$, which is 31.5-50.2 c/ha more than in the control (305.6 $\mathrm{c} / \mathrm{ha}$ ) and 4.5-23.2 c/ha higher compared to the reference option. Sugar content of root crops in the variants with seed treatment with tachigarine in the norm of $6 \mathrm{~kg} / \mathrm{t}$ was $16.5 \%$, rovral -15.9 , baseol $-15.7 \%$, and in the control variant $-14.9 \%$.

Thus, the chemical method of controlling soil pathogens, based on pre-sowing treatment of seeds with protective-stimulating substances, is a simple and affordable way to protect sugar beet from the root of seedlings and rot of root vegetables. Among the studied disinfectants, the most effective were the tachigaren, rovral and fundazol. The use of these drugs contributes to an increase in field germination of seeds (by 6.8-12.8\%) and crop yields of root crops (by 22.7-50.2 centners per hectare), as well as a decrease in the prevalence and development of root crops (by 3.9-36,6\%) and rot of root crops (by $0.4-12.8 \%$ ).

\section{Discussion}

In the fight against fusarium rot of root crops, the implementation of measures aimed at permanently limiting the parasitic activity of the pathogen in the soil and creating conditions for the growth and development of beet plants, which would support and increase the parasite's damage to plants, is of great importance. Soil microflora, its composition and activity can be enhanced in the right direction by agricultural engineering; vegetation cover is a powerful regulator of soil microflora composition. Zagurskiy (2016). pointed out that the excessive saturation of sugar beet crop rotations, the use of high doses of mineral fertilizers and other violations of agricultural technologies during the cultivation of sugar beets was the main reason for the massive damage of beet root crops during the growing season under irrigated agriculture. However, observing the scientifically based rules of agrotechnology, the spread and harmfulness of this disease can be significantly reduced. On the basis of Babakov production experience, it is established that the main problem in the formation of sugar beet yields on the non-waste mulching treatment are diseases. Accumulation of the infectious background in time is dangerous by the epiphytoty of root rot (Babakov, 2018).

Thus, an important reserve for increasing the disease resistance of plants and reducing the stockpile of infection of the pathogen in the soil is the use of agricultural techniques. Of agrotechnical methods, decisive importance is compliance with scientifically based crop rotations, proper tillage (basic and pre-sowing), careful maintenance of crops during the growing season, compliance with all the rules that contribute to the improvement of the phytosanitary condition of crops. Among the measures to fight root rot, the 
correct crop rotation with the placement of sugar beet after the most favorable predecessors is of great importance; however, it is necessary to know the optimal periods for the beet to return to the previous field. In a beet crop rotation, it is necessary to establish a crop change in which the beets would return to the old place no earlier than in 4-5 years (Maui, 2014). When changing crops, it is also necessary to keep in mind that some sugar beet precursors are affected by the same pathogens, for example, peas are affected by root rot pathogens. Therefore, in order to prevent the spread of pathogens, it is necessary to occupy highly infected areas with crops that are resistant to them (winter cereals) (Rasiukeviciute et al., 2019). In recent years, many countries have used straw as a fertilizer. Numerous studies have been conducted on the effect of this fertilizer on soil structure, humus content, water regime, nutrient balance, and other factors causing the crop yield (Körschens et al., 2013). Also conduct research on the effect of plant residues as fertilizer on the development of plant diseases. It has been established that the use of straw as a fertilizer does not contribute to an increase in the damage of wheat by pathogens of the black leg. It was revealed that plowing straw into the soil in combination with nitrogen fertilizers has a beneficial healing effect on plants (Tsvey et al., 2012).

We aware about the negative effect of elevated doses of nitrogen on plant resistance to disease (Machet et al., 2017). The results of our research also indicate a tendency to increase the defeat of sugar beet by rotting root crops and reducing the resistance of root crops to pathogens with an increase in the nitrogen rate. However, when wheat straw added, the additional nitrogen acted positively on plant resistance and on reducing the damage of sugar beet to root rot. The test of sugar beet from these fields for resistance to rot showed that the introduction of wheat straw with additional nitrogen contributed to a decrease in the susceptibility of root crops by rot by $21.0 \%$.

\section{Conclusions}

In the fight against root rot, the correct crop rotation with the placement of sugar beet after the most favorable predecessors is of great importance. Winter wheat remains the ideal predecessor for sugar beet in the south and southeast of Kazakhstan. On a natural infectious background, plowing up straw of winter wheat allows reliably reducing the susceptibility of root crops by rot, as compared to the control variant. The restoration of the initial state of soil fertility with the help of previously developed crop rotations and basic agro technical methods has become impossible. The phytosanitary condition of beet fields requires the development of new, more effective measures of recovery, infected with pathogens of root rot. The research outlined in the article on root rot of root crops is devoted to solving this actual problem.

\section{References}

Covey, P. A., Kuwitzky, B., Hanson, M., \& Webb, K. M. (2014). Multilocus analysis using putative fungal effectors to describe a population of Fusarium oxysporum from sugar beet. Phytopathology, 104(8), 886-896. https://doi.org/10.1094/PHYTO-09-13-0248$\underline{\mathrm{R}}$

Dotsenko, A.S. (1980). Causes of root rot development. Sugar Beet, 8, 33.

Ikeda, K., Banno, S., Furusawa, A., Shibato, S., Nakaho, K., Fujimura, M. (2015). Crop rotation with broccoli suppersses Verticillium Wilt of eggplant. J Gen Plant Pathol 81, 77-82. Doi: https://doi.org/10.1007/s10327-014-0559-6

Lai, X., Qi, A., Liu, Y., Mendoza, L., Liu, Z., Lin, Z., \& Khan, M. (2020). Evaluating Inoculation Methods to Infect Sugar Beet with Fusarium oxysporum f. betae and F. secorum. Plant disease, 104(5), 1312-1317. https://doi.org/10.1094/PDIS-09-19-1895-RE Landschoot, S., Audenaert, K., Waegeman, W., De Baets, B., \& Haesaert, G. (2013). Plant disease prediction using data mining and machine learning: a case study on Fusarium head blight and deoxynivalenol content in winter wheat. European Fusarium Seminar, 12th, Abstracts (pp. 75-75). Presented at the 12th European Fusarium Seminar.

Maui, A. A. (2014). Vliyaniye predshestvennikov na snizheniye vredonosnosti fuzarioznoy gnili sakharnoy svekly. Novosti Nauki Kazakhstana, 63-71.

Nurpeisov, I.A., Bastaubaeva, Sh.O., Aldekov, N.A. (2012). Vozrozhdeniye sakharnoy svekly v Kazakhstane (The revival of sugar beet in Kazakhstan). Bulletin of Agricultural Science of Kazakhstan, 8, 20-25.

Rivera, V., Rengifo, J., Khan, M., Geiser, D. M., Mansfield, M., \& Secor, G. (2008). First Report of a Novel Fusarium Species Causing Yellowing Decline of Sugar Beet in Minnesota. Plant disease, 92(11), 1589. https://doi.org/10.1094/PDIS-92-11-1589B

Secor, G. A., Rivera-Varas, V., Christ, D. S., Mathew, F. M., Khan, M. F., Varrelmann, M., \& Bolton, M. D. (2014). Characterization of Fusarium secorum, a new species causing Fusarium yellowing decline of sugar beet in north central USA. Fungal biology, 118(910), 764-775. https://doi.org/10.1016/j.funbio.2014.06.001

Selivanova, G.A. (2013). The reasons for the wide spread of root rot in the PCR. Sugar Beet, 5, $27-31$.

Simson, R., Tarlan, L., Loit, E., Eremeev, V. (2017). The effect of different pre-crops on Rhizoctonia solani complex in potato. Agron. Res., 15(3), 877-885.

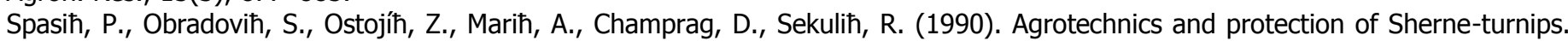
Novi Sad: Domentijan.

Zagurskiy, A. V. (2016). Influence of agrotechnical measures on the damage of sugar beet by root rots. Proceed. Int. Conf. Fundamental and applied research in bioorganic agriculture in Russia, the CIS and the EU. Moscow.

\section{Citation:}

Maui, A.A., Aipeisova, S.A., Utarbaeva, N.A., Matsyura, A.V. (2020). Effect of agrotechnical and chemical practices on Fusarium rot root in sugar beet production. Ukrainian Journal of Ecology, 10(5), 217-222. 